\title{
PROBLEMATIKA PENGGUNAAN BAHASA ACEH DI KOTA LANGSA
}

\author{
Elvira Siti Humairah ${ }^{1}$, Saifullah ${ }^{2}$, Awaluddin Arifin \\ 1, 2 Program Studi Antropologi Fakultas Ilmu Sosial dan Politik Universitas \\ Malikussaleh, Aceh-Indonesia \\ ${ }^{3}$ Program Studi Ilmu Komunikasi Fakultas Ilmu Sosial dan Politik Universitas \\ Malikussaleh, Aceh-Indonesia \\ Korespondensi: eshumairah@gmail.com
}

\begin{abstract}
AbstrakPenelitian ini bertema tentang Antropologi Linguistik yang mengkaji tentang "Problematika Penggunaan Bahasa Daerah" (Studi Antropologi Linguistik Pada Penutur Bahasa Aceh Di Kota Langsa). Secara mendalam diceritakan untuk mengetahui sejauh mana penggunaan bahasa daerah (Bahasa Aceh), yang digunakan oleh masyarakat yang ada di Kota Langsa. Penelitian ini menggunakan metode sosial kualitatif yang bersifat deskriftif dengan teknik observasi, wawancara mendalam, studi dokumentasi dan studi kepustakaan. Fenomena menurunnya penggunaan bahasa daerah sebagai bahasa ibu sudah menjadi persoalan yang sering dibicarakan oleh kalangan ahli bahasa. Hal ini tidak lepas dari perkembangan globalisasi dan modernisasi yang semakin cepat Hasil penelitian juga menunjukkan bahwa masyarakat melihat fenomena berkurangnya penggunaan Bahasa Aceh di Kota Langsa yang dihuni oleh masyarakat multikultural sebagai sesuatu yang yang lumrah terjadi. Namun, masyarakat tetap berharap agar Bahasa Aceh tetap ada di tengah masyarakat dan terus dilestarikan
\end{abstract}

Kata Kunci: Problematika, Multikulturalisme, Bahasa Daerah, Linguistik 
Aceh Anthropological Journal, Vol. 3, No. 2, hlm: 202-211, Oktober 2019

\section{A. Pendahuluan}

Bahasa merupakan suatu hal yang sangat penting dalam kehidupan manusia. Bahasa adalah alat komunikasi yang digunakan untuk berinteraksi antara satu masyarakat dengan masyarakat lainnya. Hubungan antar individu satu dengan individu lainnya tidak dapat dipisahkan dengan bahasa sebagai alat komunikasi. Indonesia sebagai sebuah negara yang kaya akan budaya dari Sabang sampai Merauke juga memiliki ragam bahasa yang berbeda di setiap daerah. Setiap daerah di Indonesia terdapat bahasa daerah beragam yang digunakan oleh masyarakat sebagai alat komunikasi dan berinteraksi dengan kelompoknya. Nanggroe Aceh Darussalam merupakan sebuah provinsi yang berada di sebelah barat Indonesia, dan memiliki bahasa daerah yang disebut Bahasa Aceh. Bahasa Aceh merupakan salah satu bahasa daerah yang ada di Provinsi Nanggroe Aceh Darussalam. Berdasarkan pemetaan bahasa yang dilakukan sejak tahun 2008 oleh Balai Bahasa Provinsi Nanggroe Aceh Darussalam, dapat diketahui bahwa bahasa daerah yang ada di Provinsi Nanggroe Aceh Darussalam sekitar 8 bahasa. Bahasa Aceh merupakan salah satu bahasa dengan jumlah penutur terbanyak.

Secara umum, bahasa pertama anak dalam keluarga etnis Aceh adalah Bahasa Aceh sehingga tidaklah berlebihan jika ada orang yang mengatakan bahwa setiap orang Aceh (etnis Aceh) pasti bisa berbahasa Aceh. Tetapi ada fenomena lain tentang berkurangnya penggunaan Bahasa Aceh di beberapa daerah yang ada di Aceh, salah satunya adalah di Kota Langsa. Menurut Agus Budi Wibowo dkk dalam Dara Fatia, Kota Langsa memiliki tingkat kemajemukan relatif tinggi dengan kedatangan para transmigran dan para pendatang lain. Di Kota Langsa, etnis Jawa merupakan etnis pribumi pendatang terbanyak. Kemajemukannya meliputi suku, agama, adat, dan budaya. Hal ini menyebabkan penggunaan bahasa daerah di Kota Langsa, khususnya Bahasa Aceh mulai pudar penuturnya. Berdasarkan data yang dihimpun oleh Pemerintah Aceh tahun 2018, Kota Langsa merupakan sebuah kota multikultural yang di dalamnya terdapat banyak suku dan budaya. Selain itu, di daerah ini juga sering terjadi perkawinan silang antar suku yang menyebabkan hilangnya budaya bahasa suku bangsa Aceh. Pencampuran budaya yang terjadi di Kota Langsa secara tidak langsung meyebabkan budaya asli masyarakat Kota 
Langsa yang bersuku Aceh pelan-pelan menghilang. Bahasa Aceh yang merupakan bahasa daerah masyarakat adalah salah satu yang paling terasa mulai ditinggalkan.

Hal ini sangat menarik untuk diteliti, mengingat bahasa adalah salah satu unsur kebudayaan dalam ilmu antropologi. Berkurangnya penutur Bahasa Aceh di Kota Langsa tidak serta merta terjadi dengan sendirinya. Fenomena tersebut pasti dilatarbelakangi oleh faktor-faktor yang tak dapat dipisahkan dengan kehidupan social masyarakat yang ada di sana. Oleh sebab itu, penelitian terkait berkurangnya pengguna Bahasa Aceh di Kota Langsa menarik dikaji secara empiris dan akademis terkait dengan hubungan bahasa dan perubahan sosial budaya.

Antropologi linguistik adalah salah satu spesialisasi dalam antropologi yang mempelajari variasi dan penggunaan bahasa dalam hubungannya dengan perkembangan waktu, perbedaan tempat komunikasi, sistem kekerabatan, polapola kebudayaan lain dari suatu suku bangsa. Antropologi linguistik menitik beratkan pada hubungan antara bahasa dan kebudayaan di dalam suatu masyarakat.

Antropologi linguistik juga mempelajari unsur-unsur budaya yang terkandung dalam pola-pola bahasa yang dimiliki oleh penuturnya, serta mengkaji bahasa dalam hubungannya dengan budaya penuturnya secara menyeluruh. Hubungan bahasa dengan kebudayaan memang erat sekali. Mereka saling mempengaruhi, saling mengisi, dan berjalan berdampingan. Yang paling mendasari hubungan bahasa dengan kebudayaan adalah bahasa harus dipelajari dalam konteks kebudayaan dan kebudayaan dapat dipelajari melalui bahasa.

Dalam buku Robert Sibarani, kajian fungsi bahasa telah banyak dilakukan para linguis sejak dahulu sebagaimana yang dapat dilihat pada uraian sebagai berikut. Secara garis besar, fungsi bahasa dapat dibagi atas fungsi mikro dan fungsi makro. Fungsi mikro, yakni penggunaan bahasa dalam fungsinya yang lebih khusus untuk kebutuhan setiap manusia.

Fungsi mikro ini meliputi fungsi bahasa yang lebih menyangkut kebutuhan individu atau kepentingan pribadi seperti: fungsi nalar, fungsi emosi, fungsi komunikatif, fungsi perekam, fungsi pengidentifikasi, fungsi fatis, fungsi member 
Aceh Anthropological Journal, Vol. 3, No. 2, hlm: 202-211, Oktober 2019

rasa senang. Fungsi-fungsi mikro tersebut berfungsi dalam kehidupan semua manusia. Setiap orang menggunakan dalam kehidupan sosialnya.

Selanjutnya, fungsi makro adalah fungsi bahasa secara lebih luas yang memenuhi kebutuhan sosial dengan melampaui kepentingan pribadi seperti: fungsi ideasional, fungsi interpersonal, fungsi estetika bahasa, fungsi tekstual, fungsi sosiologis. Fungsi-fungsi makro di atas lebih menekankan fungsi teoretis bahasa dalam sistem komunikasi. Kita dapat menggunakan fungsi-fungsi ini dalam kajian bahasa dalam kaitannya dengan kemampuan komunikatif penutur.

Selain kajian yang dilakukan oleh Robert Sibarani, banyak hasil penelitian lainnya yang melihat bagaimana manusia dalam aspek kebahasaan. Seperti penelitian yang dilakukan. Skripsi milik Erna Juwita mahasiswa Antropologi, FISIP, Universitas Malikussaleh yang berjudul "Eksistensi Bahasa Aceh Di Mata Rakyat Aceh di Keude Cunda Kecamatan Muara Dua Kota Lhokseumawe Provinsi Aceh" (2012). Skripsi inidipilih penulis sebagai salah satu penguat dalam tinjauan pustaka. Dalam skripsinya tersebut, Erna menjelaskan mengenai bagaimana bentuk eksistensi diberikan oleh masyarakat Aceh Gampong Keude Cunda terhadap bahasa Aceh. Berikutnya, penelitian tersebut juga melihat hal apa saja yang mendorong terhadap apresiasi masyarakat Aceh khususnya masyarakat Gampong Keude Cunda dalam memberikan eksistensi tersebut.

Berikutnya, penelitian juga dilakukan oleh Yusria Aqmarina seorang mahasiswa Departemen Antropologi Sosial, FISIP, Universitas Sumatera Utara, yang berjudul "Eksistensi Bahasa Tamiang di Kecamatan Seruway, Kabupaten Aceh Tamiang” (2018). Dalam skripsinya ini, Yusria Aqmarina menjelaskan mengenai permasalahan penggunaan bahasa Tamiang di kehidupan sehari-hari khususnya di kalangan anak muda. Selain itu, juga mengenai keberadaan bahasa Tamiang tersebut di kehidupan sehari hari masyarakat Kabupaten Seruway.

Berdasarkan latar belakang di atas maka rumusan masalah penelitian ini adalah, Apa yang melatarbelakangi berkurangnya penggunaan Bahasa Aceh di Kota Langsa. Dan adapun tujuan penelitian ini adalah untuk mengetahui penyebab berkurangnya penggunaan Bahasa Aceh di Kota Langsa. 
Aceh Anthropological Journal, Vol. 3, No. 2, hlm: 202-211, Oktober 2019

\section{B. Metode Penelitian}

\section{Lokasi Penelitian}

Adapun yang menjadi lokasi dari penelitian ini adalah Kota Langsa, Provinsi Aceh. Alasan penulis melakukan penelitian di daerah tersebut adalah karena Kota Langsa merupakan salah satu wilayah di Aceh yang masyarakatnya majemuk dan terdiri dari beberapa suku selain suku Aceh. Dengan keberagaman suku tersebut menjadikan perpaduan budaya mudah ditemukan, termasuk percampuran bahasa dalam kehidupan sehar-hari.

Selanjutnya, dengan keberagaman tersebut dikarenakan hamper sebagian masyarakat Kota Langsa dalam berbicara tidak menggunakan bahasa Aceh. Maka agar lokasi penelitian lebih spesifik kepada bagaimana penggunaan bahasa Aceh di Kota Langsa, peneliti menjadikan sarana publik seperti :sekolah, perkantoran, pasar, warung kopi, masjid, dan di dalam ruang lingkup publik lainnya sebagai cakupan penelitian penulis. Hal tersebut dilakukan dengan harapan agar dapat mewakili masyarakat Kota Langsa secara keseluruhan, dan agar mempermudah peneliti menemukan informan yang sehari-hari melakukan aktivitas di berbagai sudut Kota Langsa.

\section{Pendekatan Penelitian}

Di dalam penelitian ini penulis mengumpulkan data dengan menggunakan metode kualitatif. Penelitian kualitatif bertujuan untuk memahami fenomena tentang apa yang dialami oleh subjek penelitaian misalnya perilaku, persepsi, motivasi tindakan secara menyeluruh dengan menarasikan dalam bentuk kata-kata dan bahasa dengan suatu konteks khusus dan memanfaatkan berbagai metode alamiah.

\section{Jenis Dan Sumber Data}

Dalam penelitan kualitatif ada dua jenis data menurut cara memperolehnya yakni data primer dan data sekunder. Data primer merupakan hasil yang langsung di ambil dari objek penelitian dengan cara pengamatan dan wawancara langsung dengan narasumber bersangkutan. Sedangkan data sekunder merupakan sumber 
Aceh Anthropological Journal, Vol. 3, No. 2, hlm: 202-211, Oktober 2019

yang di peroleh dari dokumen literatur atau penelitian terdahulu yang di biasanya diperoleh dari buku referensi, jurnal dan media massa.

\section{Informan Penelitian}

Informan kunci (Key Informant), adalah mereka yang mengetahui dan memiliki informasi pokok atau data utama yang diperlukan dalam penelitian. Adapun yang menjadi informan kuncinya disini adalah beberapa masyarakat dari suku Aceh yang ada di Kota Langsa

Informan pendukung (Supporting Informant), yaitu mereka yang secara langsung ikut serta dalam interaksi sosial maupun pihak-pihak yang membantu memberikan informasi mengenai situasi penggunaan bahasa daerah di Kota Langsa dan lokasi penelitian. Adapun yang menjadi informan pendukung ialah para pakar budaya dan pakar akademis.

Informan Penghubung, yaitu mereka yang mampu membantu dalam menghubungkan peneliti ke infoman kunci maupun pendukung. Adapun yang menjadi informan penghubung ialah beberapa masyarakat serta kepala desa (geuchik) yang ada di Kota Langsa.

\section{Teknik Analisis Data}

Teknik analisis data yang dipakai di penelitian ini adalah teknik analisis data kualitatif. Adapun proses analisis data dilakukan dengan cara observasi (pengamatan) sebagai penguat infomasi yang telah didapat melalui wawancara dengan informan kunci dan informan tambahan, Selanjutnya, memilah atau mengklaifikasikan data yang ditemukan. Menelaah seluruh data yang sudah tersedia dari berbagai sumber seperti wawancara, catatan lapangan, dokumen pribadi, dokumen resmi, untuk mendapatkan gagasan utama. Menjelaskan dengan bentuk naratif dan tabel untuk menguatkan hasil temuan. Mengadakan reduksi data dengan cara abtraksi yaitu merangkum inti, menajamkan penjelasan, dan mengarahkan hasil penelitian agar tidak lari dari topik penelitian. Tahap terakhir dari analisis data ialah mengadakan keabsahan data hasil penelitian yang sudah dibuat melalui proses observasi, wawancara, klasifikasi data, dan studi dokumen. 
Aceh Anthropological Journal, Vol. 3, No. 2, hlm: 202-211, Oktober 2019

\section{Pembahasan}

\section{Keberagaman Masyarakat Kota Langsa}

Bahasa daerah merupakan bahasa ibu yang dimiliki oleh suatu daerah yang dalam keseharian digunakan oleh masyarakat. Namun, di daerah yang pemakaian bahasa dalam kesehariannya lebih dari satu bahasa yang dikarenakan oleh keberagaman budaya masyarakatnya, maka tidak menutup kemungkinan bahasa daerah yang pada dasarnya merupakan bahasa asli daerah tersebut akan hilang dan tinggal sejarah. Keberagaman masyarakat Kota Langsa menjadi salah satu yang melatarbelakangi berkurangnya penggunaan Bahasa Aceh dalam kesehariannya. Meski demikian, keberagaman yang ada di masyarakat Kota Langsa merupakan salah satu kekayaan yang dimiliki oleh daerah tersebut. Letaknya yang berada dekat dengan perbatasan Provinsi Aceh dengan Provinsi Sumatera Utara menjadikan Kota Langsa ramai didatangi oleh masyarakat luar daerah. Mulanya pendatang tersebut datang ke Kota Langsa dengan berbagai tujuan, seperti berdagang, melanjutkan pendidikan dan sebagainya. Namun, lama kelamaan masyarakat tersebut mendiami Kota Langsa dan mengurus kepindahan secara permanen di Kota Langsa. Hal ini menimbulkan dua sisi berbeda. Di satu sisi, keberagaman tersebut bersifat positif karena dengan adanya para pendatang masyarakat yang memang berasal dari Langsa akan lebih terpacu dalam kehidupan sosial, baik dari sudut pendidikan, kreativitas pekerjaan serta di berbagai bidang lainnya. Keberagaman membuat masyarakat asli Kota Langsa mau tak mau harus mengikuti arus agar tidak tertinggal dengan masyarakat pendatang.

Di sisi lain, banyaknya pendatang ke Kota Langsa juga membawa sisi negatif, salah satu contohnya adalah dengan adanya masyarakat pendatang yang kemudian menetap di Kota Langsa, pencampuran budaya tidak dapat dihindari. Hal tersebut sangat jelas terlihat dari segi penggunaan bahasa. Dengan adanya masyarakat pendatang yang akhirnya menetap di Kota Langsa, asimilasi budaya, dalam hal ini adalah bahasa pedatang ke dalam bahasa lokal menjadi lumrah. Penutur Bahasa Aceh mulai terbiasa menggunakan Bahasa Indonesia sebagai bahasa yang lazim digunakan oleh para pendatang tadi. Sehingga, penggunaan Bahasa Indonesia dengan penggunaan Bahasa Aceh nyaris seimbang. Di beberapa tempat yang 
Aceh Anthropological Journal, Vol. 3, No. 2, hlm: 202-211, Oktober 2019

mayoritasnya ditempati oleh para pendatang penggunaan Bahasa Aceh sebagai bahasa daerah Kota Langsa bahkan sangat sedikit dibandingkan dengan penggunaan Bahasa Indonesia.

\section{Dominasi Penggunaan Bahasa Indonesia pada Fasilitas Publik}

Fenomena berkurangnya eksistensi bahasa daerah di Indonesia merupakan sesuatu yang menarik perhatian berbagai pihak, terutama peneliti yang konsen mengamati perkembangan bahasa-bahasa daerah di Indonesia.faktor lain yang melatarbelakangi berkurangnya penggunaan bahasa Aceh di masyarakat Kota Langsa adalah kebiasaan masyarakatnya yang menggunakan Bahasa Indonesia di fasilitas publik seperti sekolah, warung kopi (café), dan perkantoran. Hal tersebut akhirnya menjadikan penggunaan bahasa Indonesia sangat dominan pada ruangruang publik seperti itu. masyarakat Kota Langsa, terutama anak-anak muda dalam kesehariannya pada fasilitas publik sudah terbiasa menggunakan Bahasa Indonesia. Salah satu contohnya adalah ketika anak-anak muda berinteraksi di warung kopi. Kebanyakan dari mereka menggunakan Bahasa Indonesia saat berada di sana. Hal ini lama kelamaan menjadi kebiasaan yang akhirnya membuat dominasi Bahasa Indonesia pada fasilitas publik tak terbendung.

Kebiasaan memang menjadi salah satu elemen yang pada akhirnya akan menjadi kebudayaan baru di tengah masyarakat. Dalam hal ini, kebiasaan masyarakat Kota Langsa menggunakan Bahasa Indonesia dalam kesehariannya pada fasilitas publik membuat dominasi penggunaan Bahasa Indonesia terhadap Bahasa Aceh kian tak berimbang. Fenomena ini merupakan salah temuan yang penulis dapatkan di lapangan terkait penelitian ini. Fakta-fakta atau temuan-temuan ini dapat menjadi rujukan untuk pihak-pihak yang memiliki ketertarikan meneliti tentang berkurangnya penggunaan Bahasa Aceh, khususnya di Kota Langsa.

\section{Lingkungan Masyarakat}

Faktor lain yang membuat penggunaan Bahasa Aceh mulai berkurang di Kota Langsa adalah faktor keluarga atau lingkungan. Kebiasaan menggunakan Bahasa Indonesia pada saat berinteraksi di rumah dan lingkungan sekitar masyarakat membuat Bahasa Aceh mulai ditinggalkan. Saat ini sebagian besar keluarga di Kota 
Langsa menggunakan Bahasa Indonesia sebagai bahasa dalam kesehariannya. Padahal, keluarga tersebut asli beretnis Aceh. Namun, karena kebiasaan mereka menggunakan Bahasa Indonesia dalam kesehariannya menjadikan Bahasa Aceh jarang digunakan dan terlupakan. Oleh sebab itu, faktor lingkungan dan keluarga juga dapat dikatakan sebagai salah satu faktor yang membuat penggunaan Bahasa Aceh di Kota Langsa berkurang. Bahasa Aceh pada masyarakat Kota Langsa berkurang karena adanya kebiasaan menggunakan Bahasa Indonesia dalam berkomunikasi di rumah-rumah. Kebiasaan menggunakan Bahasa Indonesia saat berkomunikasi di rumah pada keluarga masyarakat yang ada di Kota Langsa membuat penggunaan Bahasa Aceh makin berkurang.

\section{Kesimpulan}

Ada beberapa hal yang melatarbelakangi problematika penggunaan bahasa Aceh yaitu :

a. Masyarakat yang menetap di Kota Langsa memiliki latarbelakang budaya dan etnis yang beragam, mulai dari etnis Aceh, Mandailing, Padang dan Jawa. Kondisi ini membuat penggunaan Bahasa Indonesia di tengah masyarakat menjadi lumrah agar komunikasi terjalin dengan seragam, sehingga penggunaan Bahasa Aceh menjadi berkurang.

b. Dominasi penggunaan Bahasa Indonesia pada fasilitas publik seperti perkantoran, pasar, institusi pendidikan merupakan faktor lain yang melatarbelakangi berkurangnya penggunaan Bahasa Aceh pada masyarakat Kota Langsa

c. Lingkungan keluarga juga merupakan salah satu yang melatarbelakangi berkurangnya penggunaan Bahasa Aceh pada masyarakat Kota Langsa. Kondisi Kota Langsa yang semakin maju dan moderen turut menjadikan penggunaan Bahasa Aceh berkurang. Selain itu, kebiasaan masyarakat Kota Langsa menggunakan Bahasa Indonesia dalam keseharian juga menjadikan Bahasa Aceh mulai jarang digunakan. 
Aceh Anthropological Journal, Vol. 3, No. 2, hlm: 202-211, Oktober 2019

\section{Daftar Pustaka}

Alamsyah, Teuku,dkk, 2011. Pemilihan Bahasa Indonesia Sebagai Bahasa Pertama Anak Dalam Keluarga Masyarakat Aceh Penutur Bahasa Aceh Di Nanggroe Aceh Darussalam, Jurnal Pendidikan Bahasa Melayu, Vol.1, No. 2.

Fatia, Dara, 2017. Proses Integrasi Sosial Dalam Masyarakat Multikultural, Jurnal Ilmiah Mahasiswa FISIP Unsyiah, Vol.3 No. 1

Moleong, Lexy J, 2014. Metodologi Penelitian Kulitatif, Bandung: PT. Remaja Rosdakarya.

PPKD Provinsi Aceh, 2018. Pokok Pikiran Kebudayaan Daerah Aceh.

Santoso, Teguh, 2012. Asal Usul Bahasa Aceh. Serambi Indonesia Edisi 8 Januari 2012.

Sibarani, Robert, 2004. Antropolinguistik, Medan: Poda. 